\title{
POST-ACCESSION FEMALE MOBILITY BETWEEN POLAND AND NORWAY. NEW TRENDS AND WAYS OF THINKING ABOUT MIGRATION
}

\begin{abstract}
This paper presents recent research on Polish female migration to Norway. We focus our discussion of existing literature on this subject on issues of gendered migration trajectories, children and adult education, career paths of migrant women, and the effects of migration on families and communities in Norway and Poland. There are many thematic and methodological gaps in recent scholarship on migration of Polish women to Norway despite an increased number of research projects and publications. Most scholars center on social attitudes towards migration, and consequently decisions on migration made by women and their families.
\end{abstract}

Key words: female migration; Poland; Norway; mobility; transnationalism; social roles; gender; children and families

IZABELLA MAIN Uniwersytet im. Adama Mickiewicza, Poznań E-mail: imain@amu.edu.pl

POAKCESYJNA MOBILNOŚĆ KOBIET POMIĘDZY POLSKA A NORWEGIA.. NOWE KIERUNKI MYŚLENIA O MIGRACJI

\section{Streszczenie}

IZABELA CZERNIEJEWSKA Uniwersytet im. Adama Mickiewicza, Poznań E-mail: iza@czerniejewscy.poznan.pl

CITATION: Main, I., \& Czerniejewska, I., (2017). Post-accession Female Mobility between Poland and Norway. New Trends and New Ways of Thinking about Migration. Sprawy Narodowościowe. Seria Nowa, 2017(49). https://doi.org/10.11649/sn.1358

W tekście przedstawiamy trendy w badaniach migracji Polek do Norwegii we współczesnej literaturze. Skupiamy się na kilku wątkach: genderowych ścieżkach migracyjnych, edukacji dzieci i dorosłych, pracy zawodowej kobiet oraz wpływie migracji na sytuacje rodzin i społeczności w Norwegii i Polsce.

This work was supported by a grant from National Science Centre. No competing interests have been declared. Both authors participated in elaborating research ideas and writing the manuscript.

This is an Open Access article distributed under the terms of the Creative Commons Attribution 3.0 PL License (creativecommons.org/licenses/by/3.0/pl/), which permits redistribution, commercial and non-commercial, provided that the article is properly cited. (C) The Author(s) 2017.

Publisher: Institute of Slavic Studies, Polish Academy of Sciences 
Analizując stan wiedzy zawarty w tekstach naukowych, dostrzegamy luki w wiedzy i stosowanej metodologii. Wskazujemy również na wpływ prezentowanych trendów opisów migracji na społeczną ocenę migracji, a w konsekwencji na decyzje podejmowane przez migrujące kobiety i rodziny. Mimo wzrostu liczby projektów badawczych i publikacji naukowych dotyczących ostatnich migracji Polaków do Norwegii wiele aspektów życia Polek-migrantek nie zostało dotąd przeanalizowanych.

Stowa kluczow e: migracja kobiet; Polska; Norwegia; mobilność; transnacjonalizm; role społeczne; gender; dzieci i rodziny

\section{INTRODUCTION}

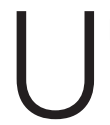

pon the accession of Poland to the European Union in 2004, Norway became an increasingly popular destination for Polish migrants due to a number of reasons including high wages and low unemployment in Norway. Demand for labour has increased, particularly in the construction and shipbuilding industries, temporary staffing agencies, domestic services, and agriculture (Iglicka \& Gmaj, 2014, p. 14; M. Pawlak, 2012). Although one can always question the reliability of statistics, particularly in the context of free movement, there is no doubt that post-2004 migration from Poland "constitutes the largest single migratory flow to Norway in history" (Friberg, 2013, p. 11).

The objective of this paper is to critically analyse existing literature on migration of Polish women to Norway by exploring several themes examined in our own ethnographic research project Mobile Lives, Immobile Realms: Female Mobility Between Poland and Norway, supported by the National Science Centre in Poland. We begin our discussion by placing our research within a broader context of Polish public discourse on migration, especially migration of women. Polish female migration is often described in contradictory terms: as an act of sacrifice, evil, pragmatism, and courage. We examine how these debates affect women's decisions to migrate and settle abroad. Furthermore, we survey the existing literature on gendered migration trajectories, career paths of migrating women, the effects of migration on families and children, including education of migrant children. The examination of these themes has allowed us to identify studies relevant to migration of Polish women to Norway. We pinpoint gaps in existing research and use an ethnographic approach to rethink some of the issues and contribute to the understanding of female migration in general.

\section{BACKGROUND: POLISH MIGRANTS IN NORWAY}

A substantial number of Poles started arriving in Norway after 2004. In 2005, there were approximately 8,000 registered Poles in Norway. By 2010, this figure reached 49,000 and by 2016 the registered Polish population increased to 95,000. Between 2000 and 2005, Polish females in Norway outnumbered men. In 2006, the ratio of Polish males and females in Norway became equal. After 2007, there was a rapid increase in the percentage of Polish male migrants-in 2009 they constituted 68 per cent of the Polish population in Norway, falling to around 65 per cent in 2015. These statistics are similar for Oslo-in 2010 the proportion of Polish women in Oslo reached 36 per cent and approximately half 
of them came to join their husbands. On 1 January 2016, there were around 10,000 children born in Norway to Polish parents. The exact number of Poles in Norway is difficult to ascertain. Starting in October 2009, Poles were allowed to live in Norway for up to three months without a residency permit. Once they stay longer and enter the labour market, they have to register with the police but can stay and work in Norway indefinitely (Czapka, 2010, p. 10). Since some Poles are circular migrants, the estimates fluctuate even more. However, it is clear that Poles outnumber other immigrants in Norway. The growth of the Polish population was very rapid and men still outnumber women.

Increased Polish migration to Norway has resulted in a growing number of research projects and scholarly publications. Most studies about Polish migrants in Norway focused on men since they constituted the majority of Polish migrants. Early research concerned emerging trajectories of labour migration from Poland, employment patterns of Polish labour migrants, and their incorporation into the Norwegian labour market (Friberg, 2010, 2012, 2013; Friberg, Arnholtz, Eldring, Hansen, \& Thorarins, 2014; Friberg \& Napierała, 2011). These studies were based on two Polonia (Polish diaspora) surveys conducted in 2006 and 2010 as well as qualitative interviews with Polish migrants in Oslo (Friberg, 2010, 2012, 2013; Friberg \& Napierała, 2011; Napierała, 2010a, 2010b). At this time many Polish migrant women were invisible in the Norwegian labour market because they worked as cleaners without contracts (Napierała, 2010b). One of the first ethnographic studies on female migration from Poland concerned the reception of Polish nurses in Norway in the early post-accession period (van Riemsdijk, 2008, 2010a, 2010b). Since 2013, several sociological and psychological studies of Poles in Norway have been undertaken. These research projects concern demographics of Polish migrants in Norway, access to welfare benefits, integration in schools, every-day life of Polish families, care deficit, work-life balance, and the use of social networks (Gmaj, Iglicka, \& Wierzejski, 2015; Pustułka, Ślusarczyk, \& Strzemecka, 2015).

\section{DEBATES ON FEMALE MIGRATION IN POLAND}

Increased female mobility is a new phenomenon that has resulted in an interesting public discourse and growing scholarship on migration of Polish women in general. In official Polish historical discourse, emigration is often perceived in moral terms (Erdmans, 1992). As Garapich (2007) writes, "In Polish emigration ideology, political exile is seen as a sacred act in the fight for freedom and economic migration as a necessary evil, a manifestation of weakness or simply cowardice, egoism and an ambiguous act of turning away from the fate of the nation." In popular parlance, emigration was also often discussed as a burden, something one must endure (White, 2011, p. 70). These narratives also relate to issues of national identity. Morawska (2003, p. 176) writes about "difficult Polishness" which "is the identity 'torn' by contradictory, positive and negative emotions toward one's own (Polish) group and by equally opposing attitudes toward 'others,' here, Germany/Germans and Europe/the European Union."

Poland has had a long history of emigration, yet female migration is problematic because of expectations regarding women's roles in the family. Polish women often face a dilemma in that their professional ambitions might not correspond with Polish society's perceptions of motherhood and more generally the role of women in family and soci- 
ety. The implications of this dilemma are important in the context of migratory motivations and decisions, including decision-making about working outside the home in Norway. Gender relations in the Polish context are highly affected by public discourses about women's roles with regard to family and children. Additionally, Polish society has strongly rooted expectations toward adult daughters, who are expected to care for their elderly parents. This facet of Polish culture often plays a significant role in the decision-making processes about migration (Goździak, 2016). Krzyżanowski (2011) indicates that "intergenerational solidarity" - expressed through grandparents' assistance in childcare and adult children's obligation to provide care for their aging parents- "represents not only a source of emotional closeness between generations but also a source of potential tensions...regulated by the norm of moral reciprocity." Intergenerational solidarity is closely tied to the stigma associated with female migration when women no longer take care of their aging parents, children or grandchildren, as is expected.

Female migration from Poland is negatively valued when women decide to migrate without their children. The discourse about "Euro-orphans" dates back to 2007, when several newspapers harshly criticized women who left their children behind "to earn money and to enjoy the good life abroad" (Urbańska, 2010). In this article we focus on Polish female migrants but we are cognizant that their experiences are not unique. Rather, they correspond to the debate on "bad migrant mothers" who left their children behind and escaped from Moldova to Turkey (Keough, 2006) as well as from El Salvador to the United States of America (Abrego, 2014). In Poland, moral panic about "irresponsible migrant mothers" resulted in a range of institutional actions. Schools were obliged to count the number of children left behind, while psychologists and educators focused on the negative and even pathological consequences of mothers' migration on children. Within this context, migration has been perceived as the main reason for psycho-social and educational problems experienced by children whose parents went abroad and for the breakdown of families as a result of separation and divorce (Gizicka, Gorbaniuk, \& Szyszka, 2010; Danilewicz, 2010). For example, BeckerPestka (2012, p. 16) argued that children "need love, care, control and the presence of both parents... Physical separation divides families and might lead to deprivation of children and youth... However, the well-being of children should have more value [for parents] than euros." Anthropologists and sociologists criticized both the concept and the discourse of "Euro-orphans" (Urbańska, 2010, 2015). Nevertheless, alarm about Euroorphans has been strong enough to allow school counsellors, psychologists, teachers, and parents to repeat arguments about the emotional harm that the migration of parents, especially mothers, can cause their children.

The debate about "irresponsible migrant mothers" can be also placed in the context of the broader political discourse about the economic situation in Poland. Due to labour shortages and Poland's aging population, the Polish government tried to undertake some actions and encourage return migration. In 2008, the government started a campaign entitled "Have you got a PLan to return?" It aimed to facilitate smooth return of Polish migrants and showcase employment opportunities in Poland. The government project failed. Poles continue to migrate to new destinations, and struggle with the social stigma attached to migrating women, especially those who leave children behind (Czerniejewska \& Goździak, 2014). It is noteworthy that public debates about women who leave children in the care of grandparents fail to mention the time-honoured tradition of grandmothers raising grandchildren in families where both parents work outside the home. The Poles who decided to 
return faced not only unemployment and a worsening financial situation but also social and cultural challenges. They no longer belong to the category of "us" (Poles) and their migratory experiences are often devaluated (Grzymała-Moszczyńska et al., 2015, p. 27).

\section{GENDERED MIGRATION TRAJECTORIES: HOW AND WHY DO WOMEN MIGRATE?}

Much of the research about post-accession Polish migration, particularly to the UK and Ireland, related to the character of migration-liquid, circular, incomplete, increasingly permanent settlers—and the identities of migrants (Burrell, 2009; White, 2016). While the intense mobility of mostly young Poles was seen as temporal, in recent years there is more migration leading to family re-unification and family formation resulting in settlement (White, 2016). It is clear that decisions about migration are structured by gender roles and ideologies, and migration depends on life expectations, labour recruitment patterns, "a global division of labour, including reproductive labour or care work, and the timing of return and patterns of settlement" (Gaetano \& Yeoh, 2010, p. 2). Gendered migration trajectories and patterns imply several scenarios of female migration that depend to a large extent on women's social and economic situation. Women are economic migrants, often working in specific sectors; they might form a family abroad, might leave a family behind or might bring a family with them to the destination country. Women follow their partners to foreign countries-either forming mixed or homogenous ethnic families. Migration for love is often intertwined with educational and economic goals. Finally, women who remain in Poland often form transnational families if their partners stay abroad for a prolonged period of time.

One of the patterns of female migration involves women following migrating partners. This phenomenon often renders women invisible in analyses of migration processes. Recent literature on international circulation of migrants with high economic status has tended to neglect families in general and women in particular, treating the latter at best as "trailing spouses" (Yeoh \& Soco, 2014). Not only does migration of "trailing spouses" contribute to household maintenance strategies — considerations about children's education and spouses' careers - but such migration is often an obstacle to female professional activity. Polish female migrants who followed their spouses making international careers and changed residence several times had difficulties finding jobs in new places. But they also acquired new skills and competences. Some started their own companies and thus exercised agency and gained opportunities for personal development (Main, 2012). While it is true that many such women decided to have children and devoted their energy to family life, they developed friendships-usually with other migrants. Not much is known about the priorities and constraints that affect the migratory experiences of Polish women when they follow their partners to Norway.

Several studies concerning recent Polish migration in Europe describe the migration of women working in the care and domestic sector. Małek (2011, p. 213) studied Polish domestic workers in Italy, whose migration was motivated by economic factors as well as consumption, emotional needs, and curiosity. Migrant women working in care sectors often started as live-in care workers, which meant very little separation of their work and private lives. Later, some migrant women moved to independent positions, rented flats and worked as hourly employees (Kordasiewicz, 2010, p. 55; Małek, 2011, pp. 60-161). Migration and work in the care and domestic sectors is often linked to separation from 
family and children (Małek, 2011; Urbańska, 2015). Most of Polish research on Polish migrants working in the care and domestic sector focused on their unprivileged position and how this led to deskilling, situating them along global discourses on female labour migration. These studies mentioned exploitation and long-hours, yet hardly ever revealed sexual harassment. It is not known if women simply did not experience sexual harassment or were silenced when talking to researchers.

Another issue mostly neglected in the literature on Polish migrants is the "white privilege," when "whiteness" is an asset and implies presence of hierarchy in society (Eade, Drinkwater, \& Garapich, 2006, p. 17). Whiteness itself is recognized as a location of power and privilege, yet it is also invisible, which permits dominant whites to deny their own position of privilege and power (van Riemsdijk, 2010, p. 221). Micheline van Riemsdijk wrote about the privilege of whiteness of Polish nurses in Norway, pointing out to its ambiguity and complexity in reference to national, ethnic, and European identities. Polish nurses experienced exclusion and stereotyping because inclusion in the "white category" is time- and place-specific. For example, there was stereotyping of Irish in the United States and Great Britain (van Riemsdijk, 2010b, p. 122). Polish nurses were seen as "naturally" caring people which led to assigning them worse tasks, resulting in them losing their technical competences through lack of use (van Riemsdijk, 2010).

A vast majority of Polish migrants moved to Norway for employment (Godzimirski, Stormowska, \& Dudzińska, 2015, p. 27) though there is little research on specific motivations. In order to begin conducting research on the reasons why women move to Norway, we should think about including a new perspective which has emerged in recent scholarship that looks at migration and work abroad as a realization of individual life projects (Christensen \& Guldvik, 2014). This perspective sees migrants as individuals who actively construct their lives within the options and conditions they are given. It allows awareness of what might be called "a new type of migrant," one who is neither a victim of the divide between the global north and the global south nor someone leaving family behind. Instead, these migrants are using any job as a part of their own life project of potential self-improvement.

\section{CAREER PATHS: BECOMING LEGAL BUT STILL UNDERVALUED}

Diverse gendered migration strategies and trajectories result in various career paths for Polish female migrants in Europe in general and in Norway in particular. Crucial to understanding how these trajectories developed is the fact that, after the collapse of communism in 1989, many Polish women made good use of the new East-West "migratory space" and constituted a significant but irregular and undocumented migrant work-force in Europe's informal economy (Coyle, 2007, p. 39; Morokvasić, Erel \& Shinozaki, 2003). Without the right to live and work in Europe before Poland joined the EU, Polish migrant women's lives and livelihoods were circumscribed by their irregular status. Although often highly educated and well qualified, they have found work primarily in low paid and low skilled jobs, mainly as domestic workers, childminders and personal carers, frequently in private households (Coyle, 2007, p. 39; Kordasiewicz, 2010; Małek, 2011; Napierała, 2010b).

There were also Polish women working legally in Europe before Poland acceded to the European Union. They either legalized their stay through means provided by being in rela- 
tionships or secured legal professional contracts. An example of a group working legally before the accession to the European Union were Polish nurses recruited by employment agencies to work in nursing homes in Norway between 2001 and 2004 as result of special labour migration schemes. Norwegian Employment Services planned to recruit at least 500 Polish nurses yet only 190 women decided to migrate (Napierała, 2010b, p. 116). It is not known how many women settled permanently. There is no research on why this offer was not attractive enough to Polish nurses-perhaps they lacked language skills, feared de-skilling, or life abroad (Goździak, 2016, p. 32). There is, however, research on Polish nurses who came as professionals to Norway. Their narratives showed the impact of the problems of exclusion and discrimination. They were actually disadvantaged in the Norwegian labour market in several ways-working in places offering little opportunity for professional advancement, in a gendered profession with low social standing, and being perceived as "not-quite-Norwegian" (van Riemsdijk, 2008, p. 207). The study of Polish nurses shows their position in the labour market, de-skilling, discrimination and stereotyping by the employers, co-workers and the Norwegian society (van Riemsdijk, 2008, 2013; van Riemsdijk \& Cook, 2013).

In May 2004, Poland became a member of the enlarged European Union. EU membership was significant for Polish women's labour mobility abroad and equality at home. As they gained the right to live and work across the EU, many of the difficulties that Polish migrant women have experienced as a consequence of their undocumented and illegal status (Lutz, 2004) eased. With the legalization of stay and work, skilled women should have been better able to access higher level occupations (Coyle, 2007, p. 39). Did that happen and what challenges persist? The Norwegian labour market is characterized by high women's labour force participation but it also is among the most gender segregated in Europe with, for example, the construction sector being predominantly male and the healthcare sector predominantly female (Baba \& Dahl-Jørgensen, 2010). Poles, like other migrants, work in Norway in different fields, yet most in less attractive positions than Norwegians. These patterns are true for women in particular (Napierała, 2010b). Perhaps the reasons for this are their unrecognized or incomparable qualifications, lack of language skills, lack of professional skills, or stereotypes and prejudices towards Poles. It is not clear from existing research what conditions and strategies allow migrant women to work and advance in their profession or find new satisfying employment.

According to a recent study (Iglicka \& Gmaj, 2014, p. 16), career options for Poles have been and continue to be limited, and Poles' career paths are confined to temporary, atypical forms of employment. Poles are exposed to less favourable treatment (lower wages, harsh working conditions and exploitation) than native residents in Norway, and are more exposed to fluctuation in labour demand. These statements are based on macro-analyses of statistics and do not provide insights into the decision making processes of female migrants. Perhaps women chose to remain at home instead of experiencing de-skilling since their partners' salaries are sufficient for their family to enjoy a good quality of life. Yet, individual choices can be only explored in in-depth qualitative research.

Norwegian integration programs are not directed at Poles, though in some municipalities Norwegian language programs were offered to Poles to help the unemployed find a job in sectors other than construction (Baba \& Dahl-Jørgensen, 2010). As Ryndyk (2013) shows, many Polish migrants worked outside their profession and below their qualifications. However, they aspired to move to more lucrative occupations and some preferred to receive unemployment benefits hoping for a professional change afterwards (Ryndyk, 
2013 , p. 44). Some women might postpone their professional activity in order to support their children's integration into the new environment, and to prepare for employment by first learning the local language, society, and culture.

Women are overrepresented in the cleaning sector. However, this group is diverse in terms of education and social capital (Erdal, 2014, p. 46). Along with Polish women without higher degrees, also more educated women decided to work as cleaners since it was the only option of employment. Polish women also work in agriculture in Norway; a study in three Norwegian municipalities of 54 farm workers showed that one quarter were women (Andrzejewska \& Rye, 2012, p. 252; Andrzejewska, 2007), yet there are no studies analysing the gender dimension in the agricultural sector. It is not known if Poles-women and men-working in agriculture had similar jobs in Poland before migrating. The context of migrant care workers in Norway and the UK was analysed by Karen Christensen and Ingrid Guldvik (2014). They showed how migration policies and general welfare and long-term care policies in the UK and Norway set the context for how migrant care workers can realize their individual life projects (Christensen \& Guldvik, 2014 , p. 41). Two articles focus on the importance of gender equality in domestic work performed by migrants in Norway (Bikova, 2010; Fjell, 2010). However, Bikova and Fjell focus on employers rather than on the migrants.

The 2006 analysis of the migrant labour market in Oslo, based on a sample of 510 Poles, showed that the labour market was extremely gendered: 92 per cent of Polish men worked in the construction industry and 72 per cent of Polish women worked in cleaning services. The small number of women who did not work as cleaners were employed in the state health service and in day care centres for children (Friberg, 2010, p. 32). Most Polish women worked in the informal economy, mainly in private homes. Most came to Norway on their own while a minority had come with partners or migrated to join significant others. Even though one third of these women are university educated, lack of Norwegian language proficiency made employment in the formal economy difficult (Friberg, 2010, pp. 39-42). Data from 2010 show that the number of Polish female migrants working illegally in cleaning services had fallen and some women were beginning to enter the formal job market (Friberg, 2012, p. 320). The employment of recent Polish migrants to Norway might have been affected by the 2008 economic crisis as well as the changing political situation in Poland and in Europe. The issues related to employment which have not been researched so far are the impact of education, language skills, social background, and length of stay in Norway on the Polish migrants access to the labour market and their employment challenges. A common scenario among young Poles is de-skilling, yet it is not clear if there are opportunities for socio-economic upward mobility in Norway and what consequences upward mobility would have for Polish women and their families.

To answer this question, it would be useful to broaden the focus of studies to include adult education undertaken in Poland (before departure) and in Norway. There are different forms of vocational education for adults and language courses that are available to immigrants (Norwegian Ministry of Education and Research, 2011; Pólturzycki, 1999). But there is no data about the adult education of Poles in Norway. Some Poles decide to take Norwegian language courses before they migrate, but the relationship between language competence, preparation for migration, adaptation strategies, and the possibilities for upward mobility in Norway have not yet been analysed. We assume that the more investment in education, the more chance the migrant has of being upwardly mobile. 
Recently, there has been an increase in family migration from Poland to Norway-families move together or reunite in Norway (Iglicka \& Gmaj, 2014, p. 12). We therefore need further research on the dynamics underlying such mobilities and their implications for gender relations. Migration significantly impacts the entire family, both those who have migrated and those who have stayed behind. However, we still do not know much about the family members and communities who remain in the sending country. Most studies focus either on the impact of remittances on the families of origin or the demographic problems faced by regions with high levels of outmigration (Cieślińska, 2012; Iglicka, 2009; Jończy, 2010). Studies have not focused on the social, psychological and cultural impact of migrant families on their relatives and friends who remain in Poland. In each migration project there are usually some family and community members who have been left behind. There is some research on children left by parents, with a special focus on the difficulties such children faced at school (Danilewicz, 2006; Gizicka et al., 2010; Walczak, 2009). But there is a knowledge gap on what is happening to the rest of the family-waiting for contacts, remittances or a return of their family members.

The concept of 'transnational families' is an interesting one in the Polish context. 'Transnational families' are defined as "families that live some or most of the time separated from each other, yet hold together and create something that can be seen as a feeling of collective welfare and unity, namely 'familyhood,' even across national borders" (Bryceson \& Vuorela, 2002, p. 3). However, for Poles it is not easily acceptable that families can be "transnational" because a family_in Polish culture-should be stable, unchangeable, and not physically separated. In Poland there is a trend to discuss migrating families in opposition to "normal" families—as incomplete or separated (Becker-Pestka, 2012; Gizicka et al., 2010). This brings negative connotations to migration projects and makes the decision to migrate more difficult for some families, especially for women.

Recent Polish migration to the EU is seen as "more fluid, with families being increasingly likely to inhabit more than one residence" (Moskal, 2010, p. 29). This means that families are constantly being reconstituted and renegotiated, adapting across spaces and through time (Moskal, 2010; Pustułka, 2012, 2014; Pustułka et al., 2015; Urbańska, 2009, 2015). The media see this situation of "family in migration" as a threat to the Polish concept of family, the Polish nation, and the state. As Urbańska (2010, p. 84) argues, the normative and moral discourse in media about Polish migration legitimizes only a family that lives in Poland in one home, "biological parents and children under one roof." White's study of Polish families shows that wives and children have important roles in decisions about migration and the reunification of family. Family reunification is in some cases evidence of a more equal relationship between spouses (White, 2011, p. 232). The issue we need to further explore-both in research and policy debates-are the consequences of moralizing and negatively evaluating migrating and transnational families.

Migration strategies of families can be diverse. In the case of Polish farm workers in Norway, it was shown that they felt an internal obligation to provide for their family's livelihood so they send remittances to families in Poland (Andrzejewska \& Rye, 2012). Parents who work abroad are expected to provide good economical standard of life to their family, but on the other hand they are obliged to give "proper" care to their children. A recent study of transnational family life of Poles in Norway shows that Polish families struggle with transnational parenting and care obligations, return visits and communica- 
tion, and changes in relationship dynamics. It is argued that transnational practices have a changing nature, dependent on life stages, particular life events, crises or transnational identifications (Bell \& Erdal, 2015, p. 95).

Changing roles of women in families with migrating members has recently become an issue of interest. The popular wisdom indicates that mothers are more often in contact with schools, that they help their children with social and educational problems, and facilitate contacts with the local community. But no evidence is gathered about the roles mothers perform abroad. It has been shown in recent research that parenthood is reconstructed in migrating families (Pustułka, 2012, 2014; Pustułka et al., 2015; Urbańska, 2009, 2015). A study of parental practices and representations of fatherhood among Polish migrant fathers in Norway placed them on a continuum of various family arrangements: between the traditional fatherhood limited primarily to being a breadwinner and the "new" engaged fatherhood (Pustutka et al., 2015). Slany and Strzemecka (2015b) studied the impact of parental employment on children both in Poland and Norway. However, these studies do not include the perspectives of the youngest family members on this situation.

There are few studies of Polish children in Norway. They are mostly concerned with education in a new country, communication between and among teachers, parents, and children. The school systems in Poland and Norway are different; problems arise when the school and the home do not share the same understanding of the role of education, and they do not communicate their different expectations (Waerdahl, 2015). Norwegian schools expect parents to be involved in their children's education. Teachers do not see lack of fluency in Norwegian to be a significant barrier to such engagement, but are dismayed by lack of willingness on the part of Polish parents to cooperate with schools. The Norwegian educational system provides access to interpreters for parents (Ślusarczyk \& Nikielska-Sekuła, 2014). However, Polish families are not treated in the same way nonEuropean immigrant families are considered (Waerdahl, 2015). Different ideas about the role of parents in the education of children do not facilitate harmonious and cooperative relationship between Polish families and Norwegian teachers (see Ślusarczyk \& NikielskaSekuła, 2014, pp. 190-194). Ślusarczyk and Pustułka (2016) emphasize that with time Polish parents learn to appreciate the Norwegian approach to education and understand that they are expected to be actively involved in their children's schooling.

Lack of successful communication between parents and teachers means that problems go unattended and result in the invisibility of children's needs in the school (Waerdahl, 2015, p. 9). It is argued that Polish children might feel lonely in a Norwegian classroom: "Polish children also struggle with picking up on the silent social language of the peer group, and thus spend a lot of time and energy making friends. Polish parents, they also struggle to pick up on the unwritten norms of parenthood" (Waerdahl, 2015, p. 10). However, we do not know how the children cope with lack of friends in the classroom or how some parents manage to successfully cooperate with schools. We also do not know what strategies are used by both sides (teachers and parents) in communicating and what protective factors affect the children's well-being in Norwegian schools.

Since family is such an important construct for Polish migrants and family values are non-negotiable, it is important to study differences between Norwegian and Polish approaches to parenting. Barnevernet, the Norwegian Child Welfare Services, provides assistance and support to children, adolescents, and parents who are experiencing difficulties within the family. Media, internet, and some studies report that Polish parents do not understand the mission of this institution. They dispute its value and are afraid that 
children can be taken away from them for capricious reasons (Erdal \& Ezzati, 2014, p. 10; Godzimirski et al., 2015, pp. 30-32; Sokół-Rudowska, 2013, p. 15; Waerdahl, 2015, p. 7). This shows how different norms and values of Polish parents and those of the Norwegian care system can lead to misunderstandings; these differences should therefore be subject of further study. Focusing on different sets of cultural norms and expectations in "peaceful" settings could contribute to better mutual understanding.

There is also a knowledge gap when it comes to appreciating the social environment of Polish children-how they make friendships, how their social networks function outside the school, or if they have other peer groups. Not much is known about the support of mothers and fathers in helping children to socialize with other peers-Polish, Norwegian or other foreigners. We also know nothing about the role children play in familieswhat family decisions the child might influence and what expectations parents might hold about his or her future.

Recent studies of Polish children living in Norway focus on their sense of belonging and everyday experiences (Pustułka et al., 2015). One study showed that children's sense of attachment to Poland is formed by contacts with the family who remain behind, as well as with Polish peer groups in Poland and Norway (or lack of such contacts). Sense of belonging to Norwegian society is created by everyday life and school culture. Polish children saw the difference between two countries mostly in terms of food and leisure time. Another sociological study of Polish children in Norway focused on their identities and belonging (Slany \& Strzemecka, 2015a, 2015b). We already know that Polish children and families in Norway have their own networks, structures, rules, and their transnationality can differ in "ways of doing" (such as sending money, visiting, or talking on Skype) and "ways of being" (such as emotional attachments, identity construction processes, and negotiating belonging) (Bell \& Erdal, 2015, p. 79). The relationship among children from transnational and immigrant families (Seeberg, 2003) is another important element to study. The aforementioned studies focused on issues of identity and belonging, while other aspects were missing. Moreover, they missed multi-sited perspectives that indepth anthropological research would bring out. The migratory and transnational life is only studied in Norway while, as was mentioned before, experiences in communities that people migrate from are not known and should be studied profoundly.

Many authors still conceptualize migration as leading to family breakdown and ask the following questions: What are the social and emotional costs caused by separation between parents and children due to migration? To what degree can these costs be compensated by remittances? What are the risks for children left behind? (Castaneda \& Buck, 2011; Cortés, 2008; De la Garza, 2010). However, Polish authors write mostly about the psychological and social consequences for families separated by migration (Brzezińska \& Matejczyk, 2011; Danilewicz, 2006; 2010; Gizicka et al., 2010; A. Pawlak, 2014). There is not much reflection on the broader situation of family members who stayed in Poland. Authors repeat frequently that, in households "without women," children have educational and social problems - they might use alcohol, drugs or lose sense of life (Kuźma, 2013 , p. 12). On the contrary, in a study of El Salvadoran transnational families, Abrego (2014, p. 145) described some very diverse consequences that parental migration had for children. These included a higher level of economic well-being, in some cases leading to better nutrition, private schooling, and surplus money. Emotional well-being could improve too, and children went from distraught to understanding the trade-off between gains and losses (Abrego, 2014, p. 145). 
Polish migration to European countries has increased since Poland's accession to the EU. Along with the increase in migration, the number and scope of studies has expanded. The literature on Polish migrants is gradually growing in the receiving countries as well as in Poland. Qualitative sociological and anthropological studies address how migrants adapt in a receiving society as well as the challenges migrants face when it comes to questions of identity and belonging and plans to settle or return. These studies provide a rich picture of Polish migration in several European countries, yet there is often lack of reflection on discourses and discussion in Polish media and society concerning migration, and especially migration of women. There is a negative attitude towards migrating women and migrating parents. Transnational families are seen as a problem-a product of a media-created moral panic about so called "Euro-orphans." Understanding the impact of these discourses on the actual migrants and their families in Poland and abroad has not been studied so far.

Recent studies about Poles in several countries show a change in migration patterns from the temporal, economic migration of males to more permanent migration of whole families. As this pattern is still quite new, it is very interesting to study the whole context of its emergence. This context includes the factors which influence migrants' decisionmaking processes, especially gendered conceptions of what migration entails. Little is known about different migration patterns-Polish women might stay in their country of origin when their partners migrate, follow their partners to a foreign country, or come back after some time living abroad. Equally, they might also be the principal agent in the migration project. But what are the reasons and consequences of such decisions for them and their families? How does gender impact immigrant integration strategies and how does migration affect gender roles and responsibilities in receiving and sending communities?

These are all important questions. But gaps in research still exist when it comes to how female migrants maintain relationships with their families in Poland and Norway, the options they have for finding satisfying employment and career advancement, the educational possibilities open to them, the potential challenges they face, and ultimately how they are able to adapt. Polish female migrants in Norway use various strategies to find employment, yet their work trajectories have been hardly studied so far. The Norwegian labour market is characterized by high women's labour force participation. Polish female migrants usually work in cleaning services, the health service and in children's day care centres. They also work in private households. But we do not know what the impact of education and adaptation processes are on participation in the labour market.

It is not known how the family structure changes as result of migration of one family member or entire family, or what the impact of migration is on the extended family (grandparents, cousins, parental siblings) residing in Poland. It is known from previous research that some Poles in Norway form transnational families, yet very little is known on how these families function. Few studies on Polish children in Norway explore questions of identity and belonging, yet little is known on how children function in transnational families, or after their return to Poland. In particular, the situation of family members in communities where people migrate from has not been explored. In such transnational contexts, the identity and attitudes of children and families toward Poland and Norway are changing contextually, and the means of adapting into a new society and maintaining contact with Poland can be very different. 
Many of these issues can be addressed in ethnographic research that combines observations and interviews with several family members. Even though there are many studies of Polish migrants in various contexts, there are hardly any studies taking a multi-sited approach. Such an approach—studying migrants and their families "there" and "here"-would bring a new and fresh way of looking at female migration as a process of becoming, negotiating and changing social roles and cultural values.

A recent study of the motivations of Polish women who migrate and settle abroad argues that, "in many cases the reasons changed over time and often switched from romantic, emotional and spontaneous to more practical, based on considering standard and quality of life" (Main, 2016). Female migrants have a strong transnational connection with Poland and continuously compare their educational and career opportunities, quality and access to healthcare, and their standard of life (Main, 2016). Norway is a new destination of female and family migration from Poland and researchers should focus on identifying the nature of this new migratory trend. Is it pragmatic or romantic, temporal or permanent, intertwined with transnational or national discourses?

\section{BIBLIOGRAPHY}

Abrego, L. J. (2014). Sacrificing families: Navigating laws, labor, and love across borders. Stanford, CA: Stanford University Press.

Andrzejewska, J. (2007). Mobile livelihoods: Social practices of Polish farm labour migrants in Norway. XXII ESRS Congress 24.

Andrzejewska, J., \& Rye, J. F. (2012). Lost in transnational space?: Migrant farm workers in rural districts. Mobilities, 7(2), 247-268. https://doi.org/10.1080/17450101.2012.654996

Baba, M. L., \& Dahl-Jørgensen, C. (2010). Work migration from Poland to Norway: A new institutional approach. iNtergraph: journal of dialogic anthropology, 2(2) (Work life: Flexibility, globalization, life-project and identity).

Becker-Pestka, D. (2012). Rodzina w obliczu migracji zarobkowej. Colloquium Wydziału Nauk Humanistycznych i Społecznych: Kwartalnik, 1(5), 9-26.

Bell, J., \& Erdal, M. B. (2015). Limited but enduring transnational ties?: Transnational family life among Polish migrants in Norway. Studia Migracyjne - Przegląd Polonijny, 2015(3), 77-98.

Bikova, M. (2010). The snake in the grass of gender equality: Au-pairing in women-friendly Norway. In L. W. Isaksen (Ed.), Global care work: Gender and migration in Nordic societies (pp. 49-68). Lund: Nordic Academic Press.

Bryceson, D., \& Vuorela, U. (2002). Transnational families in the twenty-first century. In D. Bryceson \& U. Vuorela (Eds.), The transnational family: New European frontiers and global networks, cross-cultural perspectives on women (pp. 3-30). London: Berg.

Brzezińska, A. I., \& Matejczyk, J. (2011). Psychologiczne konsekwencje (euro)sieroctwa: funkcjonowanie rodziny, diagnoza i pomoc. Studia Edukacyjne, 2011(17), 71-87.

Burrell, K. (2009). Polish migration to the UK in the 'new' European Union: After 2004. Aldershot: Ashgate Publishing Limited.

Castaneda, E., \& Buck, L. (2011). Remittances, transnational parenting, and the children left behind: Economic and psychological implications. The Latin Americanist, 55(4), 85-110. https://doi.org/10.1111/j.1557-203X.2011.01136.x 
Christensen, K., \& Guldvik, I. (2014). Migrant care workers: Searching for new horizons. Farnham: Ashgate.

Cieślińska, B. (2012). Emigracje bliskie i dalekie: Studium wspótczesnych emigracji zarobkowych na przykładzie województwa podlaskiego. Białystok: Wydawnictwo Uniwersytetu w Białymstoku.

Cortés, R. (2008). Children and women left behind in labor sending countries: An appraisal of social risks: Working paper. New York, NY: Division of Policy and Practice UNICEF.

Coyle, A. (2007). Resistance, regulation and rights: The changing status of Polish women's migration and work in the 'new' Europe. European Journal of Women's Studies, 14(1), 37-50. https://doi.org/10.1177/1350506807072316

Czapka, E. A. (2010). The health of Polish labour immigrants in Norway (Norwegian Center for Minority Health Research).

Czerniejewska, I., \& Goździak, E. M. (2014). "Aiding defeated migrants": Institutional strategies to assist Polish return migrants. International Migration, 52(1), 87-99.

Danilewicz, W. (2006). Sytuacja życiowa dzieci w rodzinach migracyjnych. Białystok: Wydawnictwo Uniwersyteckie Trans Humana.

Danilewicz, W. (2010). Rodzina ponad granicami: Transnarodowe doświadczenia wspólnoty rodzinnej. Białystok: Wydawnictwo Uniwersyteckie Trans Humana.

De la Garza, R. (2010). Migration, development and children left behind: A multidimensional perspective. Social and Economic Policy Working Paper. New York, NY: UNICEF. Policy and Practice.

Eade, J., Drinkwater, S., \& Garapich, M. (2006). Class and ethnicity -- Polish migrants in London. London: CRONEM.

Erdal, M. B. (2014). Praca i rodzina: Rozważania o powrocie wśród Polaków mieszkających w Norwegii. Studia Migracyjne - Przegląd Polonijny, 2014(2), 41-64.

Erdal, M. B., \& Ezzati, R. T. (2014). 'Where are you from' or 'When did you come'?: Temporal dimensions in migrants' reflections about settlement and return. Ethnic and Racial Studies, 38(7), 1202-1217. https://doi.org/10.1080/01419870.2014.971041

Erdmans, M. P. (1992). The social construction of emigration as a moral issue. Polish American Studies, 49(1), 5-25

Fjell, T. I. (2010). Doing gender equality: Cleaners employed in Norwegian middle-class homes. In L. W. Isaksen (Ed.), Global care work: Gender and migration in Nordic societies (pp. 97-114). Lund: Nordic Academic Press.

Friberg, J. H. (2010). Working conditions for Polish construction workers and domestic cleaners in Oslo: Segmentation, inclusion and the role of policy. In R. Black, G. Engbersen, \& M. Okólski (Eds.), A continent moving west?: EU enlargement and labour migration from Central and Eastern Europe (pp. 23-50). Amsterdam: Amsterdam University Press.

Friberg, J. H. (2012). The 'guest-worker syndrome' revisited?: Migration and employment among Polish workers in Oslo. Nordic Journal of Migration Research, 2(4), 316-324. https://doi.org/10.2478/v10202-012-0002-z

Friberg, J. H. (2013). The Polish worker in Norway: Emerging patterns of migration, employment and incorporation after EUs Eastern enlargement (Ph.D. dissertation). University of Oslo, Oslo.

Friberg, J. H., Arnholtz, J., Eldring, L., Hansen, N. W., \& Thorarins, F. (2014). Nordic labour market institutions and new migrant workers: Polish migrants in Oslo, Copenhagen and Reykjavik. European Journal of Industrial Relations, 20(1), 37-53. https://doi. org/10.1177/0959680113516847 
Friberg, J. H., \& Napierała, J. (2011). Polscy migranci w Norwegii. In P. Kaczmarczyk (Ed.), Mobilność i migracje $w$ dobie transformacji, wyzwania metodologiczne (pp. 38-67). Warszawa: Wydawnictwo Naukowe Scholar.

Gaetano, A. M., \& Yeoh, B. S. A. (2010). Introduction to the Special Issue on Women and Migration in Globalizing Asia: Gendered Experiences, Agency, and Activism. International Migration, 48(6), 1-12. https://doi.org/10.1111/j.1468-2435.2010.00648.x

Garapich, M. (2007). Odyssean refugees, migrants and power - Construction of 'other' within the Polish 'community' in the UK. In D. Reed-Danahay \& C. Brettell (Eds.), Immigration and citizenship in Europe and the U.S.: Anthropological perspectives (pp. 124-161). New Brunswick, NJ: Rutgers University Press.

Gizicka, D., Gorbaniuk, J., \& Szyszka, M. (2010). Rodzina w sytuacji rozłąki migracyjnej. Lublin: Wydawnictwo KUL.

Gmaj, K., Iglicka, K., \& Wierzejski, A. (2015). Settlement choices in Norway (WP 6 Working Paper). Kraków: Jagiellonian University.

Godzimirski, J. M., Stormowska M., \& Dudzińska, K. (2015). Nowe diaspory w Europie i zarządzanie migracją: Przypadek Polaków w Norwegii. Warszawa: Polski Instytut Spraw Międzynarodowych, Instytut Studiów Politycznych Polskiej Akademii Nauk, Norweski Instytut Spraw Międzynarodowych.

Goździak, E. (2016). Biała emigracja: Variegated mobility of Polish care workers. Social Identities: Journal for the Study of Race, Nation and Culture, 22(1), 26-43. https://doi. org/10.1080/13504630.2015.1110354

Grzymała-Moszczyńska, H. et al. (2015). (Nie)łatwe powroty do domu?: Funkcjonowanie dzieci i młodzieży powracających z emigracji. Warszawa: Fundacja Centrum im. prof. Bronistawa Geremka.

Iglicka, K. (2009). Powroty Polaków w okresie kryzysu gospodarczego: W pętli pułapki migracyjnej: Raport z badań. Raporty i Analizy: Centrum Stosunków Międzynarodowych, 2009(1), 1-32.

Iglicka, K., \& Gmaj, K. (2014). Poland - past and current migration outflows with the special emphasis on Norway. Reports and Analyses: Centre for International Relations, 2014(4).

Jończy, R. (2010). Migracje zagraniczne z obszarów wiejskich województwa opolskiego po akcesji Polski do Unii Europejskiej: Wybrane aspekty ekonomiczne i demograficzne. Opole: Wydawnictwo Instytut Śląski.

Keough, L. J. (2006). Globalizing 'postsocialism': Mobile mothers and neoliberalism on the margins of Europe. Anthropological Quarterly, 79(3), 431-461. https://doi.org/10.1353/ anq.2006.0036

Kordasiewicz, A. (2010). Profesjonalizacja i personalizacja - strategie Polek pracujących w sektorze usług domowych w Neapolu. In M. Kindler \& J. Napierała (Eds.), Migracje kobiet: Przypadek Polski (pp. 37-68). Warszawa: Wydawnictwo Naukowe Scholar.

Krzyżanowski, Ł. (2011). In the trap of intergenerational solidarity: Family care in Poland's ageing society. Polish Sociological Review, 173(1), 55-78.

Kuźma, E. (2013). Migracje Polek z obszarów peryferyjnych kraju do metropolii europejskich: Analiza społecznych konsekwencji współczesnej mobilności przestrzennej kobiet na przykładzie Podlasianek w Brukseli. In Młoda polska emigracja w UE jako przedmiot badań psychologicznych, socjologicznych i kulturowych: EuroEmigranci.PL, Kraków. 
Lutz, H. (2004). Life in the twilight zone: Migration, transnationality and gender in the private household. Journal of Contemporary European Studies, 12(1), 47-55. https://doi. org/10.1080/1460846042000207114

Main, I. (2012). High mobility of Polish women: The ethnographic inquiry of Barcelona. International Migration, 52(1), 130-145. https://doi.org/10.1111/imig.12119

Main, I. (2016). Motivations for mobility and settlement of Polish female migrants in Barcelona and Berlin. Social Identities: Journal for the Study of Race, Nation and Culture, 22(1), 62-79. https://doi.org/10.1080/13504630.2015.1110358

Małek, A. (2011). Migrantki - opiekunki: Doświadczenia migracyjne Polek pracujących w Rzymie. Kraków: Wydawnictwo Uniwersytetu Jagiellońskiego.

Morawska, E. (2003). National identities of Polish (im)migrants in Berlin: Four varieties, their correlates and implications. In W. Spohn \& A. Triandafyllidou (Eds.), Europeanisation, national identities and migration changes in boundary constructions between Western and Eastern Europe (pp. 171-191). London: Routledge.

Morokvasić, M., Erel, U., \& Shinozaki, K. (2003). Crossing borders and shifting boundaries: Vol. 1. Gender on the move. Opladen: Springer Fachmedien Wiesbaden. https:// doi.org/10.1007/978-3-663-09529-3

Moskal, M. (2010). Transnationalism and the role of family and children in inter-European labour migration. European Societies, 13(1), 29-50. https://doi.org/10.1080/14616696. 2010.497225

Napierała, J. (2010a). Niewidzialne pracownice? - przypadek migrantek z Polski na rynku pracy w Oslo. In M. Kindler \& J. Napierała (Eds.), Migracje kobiet: Przypadek Polski (pp. 114-137). Warszawa: Wydawnictwo Naukowe Scholar.

Napierała, J. (2010b). Sytuacja Polek na rynkach pracy w Danii i Norwegii w okresie poakcesyjnym. Studia Migracyjne - Przegląd Polonijny, 2010(4), 55-78.

Napierała, J., \& Trevena, P. (2010). Patterns and determinants of sub-regional migration: A case study of Polish construction workers in Norway. In R. Black, G. Engbersen, \& M. Okólski (Eds.), A continent moving west?: EU enlargement and labour migration from Central and Eastern Europe (pp. 51-71). Amsterdam: Amsterdam University Press.

Norwegian Ministry of Education and Research. (2011). Education - from kindergarten to adult education. Oslo: Norwegian Ministry of Education and Research. Retrieved 2 August 2017, from http://www.udir.no/Upload/Brosjyrer/5/Education_in_Norway. pdf?epslanguage $=$ no

Pawlak, A. (2014). "Poczytaj mi mamo przez Skype'a": Negocjowanie zakresu i modyfikowanie ról rodzinnych w rodzinach z doświadczeniem emigracji zarobkowej. Pogranicze: Studia Społeczne, 24, 49-72. https://doi.org/10.15290/pss.2014.24.04

Pawlak, M. (2012). Transformacja i rekonstrukcja tożsamości narodowej polskich imigrantów w Norwegii (Ph.D. dissertation). Instytut Etnologii i Antropologii Kulturowej, Wydział Historyczny, Uniwersytet im. Adama Mickiewicza, Poznań.

Półturzycki, J. (1999). Edukacja dorosłych w Norwegii. In J. Półturzycki (Ed.), Edukacja dorosłych za granicą (pp. 114-130). Toruń: Wydawnictwo Adam Marszałek.

Pustutka, P. (2012). Polish mothers on the move: Transnationality and discourses of gender, care, and co-residentiality requirement in the narratives of Polish women raising children in the West. Annales Universitatis Paedagogicae Cracoviensis: Studia Sociologica, 2(4), 162-175.

Pustułka, P. (2014). Parenting in the context of migration: Child-centred narratives of Polish migrant mothers: Cross-generational identity construction abroad. Studia Migracyjne - Przegląd Polonijny, 2014(3), 151-170. 
Pustułka, P., Ślusarczyk, M., \& Strzemecka, S. (2015). Polish children in Norway: Between national discourses of belonging and everyday experiences of life abroad. In Z. Millei \& R. Imre (Eds.), Childhood and nation: Interdisciplinary engagements (pp. 207-227). London: Palgrave Macmillan.

Riemsdijk, M. van. (2008). Immigration, belonging and the politics of difference: Narratives of Polish nurses in Norway. PhD dissertation. Department of Geography. Ann Arbor: University of Colorado.

Riemsdijk, M. van. (2010a). Neoliberal reforms in elder care in Norway: Roles of the state, Norwegian employers, and Polish nurses. Geoforum, 41(6), 930-939. https://doi. org/10.1016/j.geoforum.2010.06.008

Riemsdijk, M. van. (2010b). Variegated privileges of whiteness: Lived experiences of Polish nurses in Norway. Social \& Cultural Geography, 11(2), 117-137. https://doi. org/10.1080/14649360903514376

Riemsdijk, M. van. (2013). Everyday geopolitics, the valuation of labor and the socio-political hierarchies of skill: Polish nurses in Norway. Journal of Ethnic and Migration Studies, 39(3), 373-390. https://doi.org/10.1080/1369183X.2013.733859

Riemsdijk, M. van, \& Cook, M. (2013). International talent recruitment to Norway: Opportunities, challenges, and lived experiences of skilled migrants. Oslo: Fafo.

Ryndyk, O. (2013). Welfare and migration: Transitions into and out of the welfare benefits receipt among Polish migrant workers in Norway (European Master in Migration and Intercultural Relations). University of Stavanger.

Seeberg, M. L. (2003). Dealing with difference: Two classrooms, two countries: A comparative study of Norwegian and Dutch processes of alterity and identity, drawn from three points of view. Oslo: NOVA. https://doi.org/10.7577/nova/rapporter/2003/18

Slany, K., \& Strzemecka, S. (2015a). Children's experience of growing up transnationally (WP5 Research Report No. 1).

Slany, K., \& Strzemecka, S. (2015b). Gender roles and practices in Polish migration families in Norway through the eyes of children. Migration Studies - Polish Diaspora Review - Polish Transnational Families in United Europe, 2015(3), 157-181.

Sokót-Rudowska, M. (2013). Us among them: A study of the contemporary Polish emigration to Norway. Studia Humanistyczne AGH, 12(1), 9-24. https://doi.org/10.7494/ human.2013.12.1.9

Ślusarczyk, M., \& Nikielska-Sekuła, K. (2014). Między domem a szkołą: Dzieci migrantów w systemie edukacyjnym: Kontekst norweski. Studia Migracyjne - Przegląd Polonijny, 40(2(152)), 177-202.

Ślusarczyk, M., \& Pustułka, P. (2016). Norwegian schooling in the eyes of Polish parents: From contestations to embracing the system. Central and Eastern European Migration Review, 5(1), 49-69. https://doi.org/10.17467/ceemr.2016.06

Urbańska, S. (2009). Matka migrantka: Perspektywa transnarodowości w badaniu przemian ról rodzicielskich. Studia Migracyjne - Przegląd Polonijny, 35(1), 61-84.

Urbańska, S. (2010). „Cała Polska liczy eurosieroty”: Panika moralna i płeć w wykluczeniu oraz stygmatyzacji rodzin migrantów. Kultura i Społeczeństwo, 54(3), 61-88.

Urbańska, S. (2015). Matka Polka na odległość: Z doświadczeń migracyjnych robotnic 1989-2010. Toruń: Wydawnictwo Naukowe Uniwersytetu Mikołaja Kopernika.

Waerdahl, R. (2015). Integration and re-integration of Polish children in school: Part 1. Inclusion of Polish children in Norwegian schools (WP7 Working Report, Centre for International Relations). 
Walczak, B. (2009). Dziecko w sytuacji rozłąki migracyjnej. In M. Duszczyk \& M. Lesińska (Eds.), Współczesne migracje: Dylematy Europy i Polski (pp. 149-173). Warszawa: Ośrodek Badań nad Migracjami.

White, A. (2011). Polish families and migration since EU accession. Bristol: The Policy Press.

White, A. (2016). Polish migration to the UK compared with migration elsewhere in Europe: A review of the literature. Social Identities, 22, 10-25. https://doi.org/10.1080/1350 4630.2015.1110352

Yeoh, B. S. A., \& Soco, M. A. (2014). The cosmopolis and the migrant domestic worker. Cultural Geographies, 21, 171-187. https://doi.org/10.1177/1474474014520899

\section{WEBPAGES:}

https://www.ssb.no/en/befolkning/statistikker/innvbef/aar (17.03.2016)

http://www.transfam.socjologia.uj.edu.pl (17.03.2016)

http://migrationnavigator.org (17.03.2016)

http://goodgov.pism.pl/en (17.03.2016)

http://polfamigra.umcs.pl/en/ (17.03.2016) 